by Barry J. Cooper ${ }^{l}$ and David F. Branagan ${ }^{2}$

\title{
The 25th International Geological Congress, Sydney, Australia (1976)
}

\author{
1 School of Natural \& Built Environments, University of South Australia, Adelaide SA 5000. E-mail: barry.cooper@unisa.edu.au \\ 2 School of Geosciences, University of Sydney, NSW 2006, Australia.E-mail: dbranaga@mail.usyd.edu.au
}

(Received January 1, 2015; Revised Accepted June 20, 2015)

\section{Introduction}

The $25^{\text {th }}$ International Geological Congress (IGC) in Sydney, 1625 August 1976, was the first held in the Australian region and, except for the 1929 Congress in Pretoria, South Africa, also the first in the southern hemisphere. Most recently the Congress returned to Australia with the $34^{\text {th }}$ IGC in 2012 in Brisbane.

The 1976 Congress occurred at a pivotal moment in the history of Australian geology. The $19^{\text {th }}$ - and early $20^{\text {th }}$-century pioneering phase of Australian geology was long past (Branagan, 2012). In the previous 30 years, geological teaching at universities had blossomed, and many graduate geologists were finding employment. The Geological Surveys in every Australian State had also grown dramatically. Most importantly, a national geological survey, then known as the Bureau of Mineral Resources, Geology and Geophysics (or simply BMR), had been formed in 1946, with a major role to support State Geological Surveys in systematic geological mapping of the continent. Some State surveys even feared a national "takeover". The BMR had rapidly expanded the knowledge of Australian geology. One consequence was dramaticallyincreased interest in minerals and petroleum.

In 1953 the $5^{\text {th }}$ Empire Mining and Metallurgical Congress was successfully held in Australia and New Zealand with international participation. A significant collaborative national geology volume resulted (Edwards, 1953). In the same year a notable, but ultimately uneconomic, oil discovery occurred at Rough Range in Western Australia. Natural gas discoveries followed during the 1960s in Queensland, South Australia, and Victoria. The $8^{\text {th }}$ Commonwealth Mining and Metallurgical Congress returned to Australia in 1965. Five volumes dealing with mineral exploration, mineral deposits and petroleum were published. Major resurgence in mineral exploration and mining development then underway culminated in the "Nickel Boom" of 1969-1970 (with following bust). Large scale iron ore mining and exports commenced from Western Australia in the mid1960s in tandem with major expansion of coal mining in NSW and Queensland. By the $25^{\text {th }}$ IGC in 1976, Australia had a large, active, yet youthful population of geologists, increasingly knowledgeable about their geology, self-confident and assertive on a national level, and involved in international geological networks. In more ways than one, Australian geology had "come of age".

Staging the $25^{\text {th }}$ IGC in Sydney brought Australia and surrounding countries, including New Zealand and the newly independent Papua New Guinea, into the forefront of world geology for the first time.
Previously the region was remote in the eyes of the international geological community. The $25^{\text {th }}$ IGC was also a major national effort by Australian geologists coupled with significant input from their New Zealand colleagues.

It is a challenge to convey the general air of excitement amongst the Australian geological community during the 1976 IGC. For many, particularly the younger generation, it provided the first meeting with many leaders in their field, people previously known only from their papers and written correspondence, which was still tortuously slow.

The following information utilises extensively the "General Proceedings" of the 25th IGC published after the Congress (Renwick, 1977).The personal memories of the authors and other participants have been invaluable. Harrington (2007) also advised that extensive $25^{\text {th }}$ IGC day-to-day records should be available in the Australian Government Archives.

\section{Invitation}

As early as 1956, the Geological Society of Australia (GSA), founded in 1952, considered holding the IGC in Australia (Cooper, 1994) and approached the Australian Academy of Sciences (founded in 1954), whose National Committee for Geological Sciences played an important role in the subsequent Congress bid. At the November 1964 meeting of the GSA's governing Council, then President, John Dulhunty, advised of discussions then being held with N.H. Fisher (BMR) about the prospect. The meeting agreed "to give notice of the intention to lodge an invitation for the IGC in Australia in 1972 or nearest available year thereafter". In 1966 an Advisory Committee was established, including subsequent GSA President M.R. Banks, N.H. Fisher, H.G. Raggatt, J.J. Frankel, H.F. King and E.A. Rudd, to pursue the proposal with the Academy. In August 1966 the Society also organised its first Specialists' Meeting in Adelaide with an outback field trip to the Flinders Ranges. Such an event was organised again in 1968 in Canberra, followed by the First International Archaean Symposium in Perth in May 1970 and the First Australian Geological Convention, again in Adelaide, in May 1975. Thus the national organisational capacity of GSA was demonstrated.

Ultimately the Congress was sponsored by the Australian Academy of Sciences, represented by M.F. Glaessner, in collaboration with GSA. The Academy was the primary vehicle of communication between the Australian Federal Government and international agencies, including UNESCO, IUGS and the IGC administration that 
arranged each Congress. A formal bid to host the IGC was lodged at the $23^{\text {th }}$ IGC in Prague in 1968, even though that IGC had been largely aborted following the concurrent Soviet invasion of Czechoslovakia (Schneer, 1995).It was confirmed at the $24^{\text {th }}$ IGC in Montréal, Canada in 1972. This was a time of much uncertainty within the international geological community about holding future IGCs, due to the costs and amount of organisation required. However the unopposed Australian offer for 1976 with its demonstrated organisational capacity overrode those concerns.

In many ways, Norman H. Fisher (BMR Director and Chief, 19691974) was the primary instigator of the $25^{\text {th }}$ IGC. He became Chairman of the Organising Committee and President of the Congress, although initially Martin F. Glaessner, representing the Australian Academy of Sciences, had expected that position (Harrington, 2007) (Fig 1). Fisher's contribution was recognised during the Congress by award of the L.A. Spendiarov Prize by the USSR Academy of Sciences. A. (Sandy) Renwick, a senior geologist, who previously worked in Papua New Guinea, proved an excellent and efficient Secretary General of the Congress after the initial appointee proved inefficient under pressure. Renwick's full-time position based in a large room within the BMR in Canberra reflected recognition of his important role. Overall institutional support, especially from the BMR but also from most Australasian universities and geological surveys, guaranteed an extremely successful Congress.

The full $25^{\text {th }}$ IGC Organising Committee, established in 1972, consisted of N.H. Fisher (Chairman), A. Renwick (Secretary General), D.A. Brown, J.N. Casey, P.F. Howard, I. McDougall, D.J. McGarry, P.D. O'Connor (Academy of Science), W.J. Perry, G.M. Philip, G. Rose, together with one representative each from QANTAS Airlines and Trans Australian Airlines (TAA), the latter then operating as a separate Australian domestic air carrier. All members of the exclusively male committee were based either in Sydney or Canberra, the latter initially a competing Australian city for the Congress.

Other States were represented on the 20 strong Advisory Committee, including Dorothy Hill from Queensland, the only female geologist in the main Congress administration. Regional Excursion Committees, each composed of 2-5 geologists, were established in every Australian State and the Northern Territory, as well as in New Zealand and Papua New Guinea.

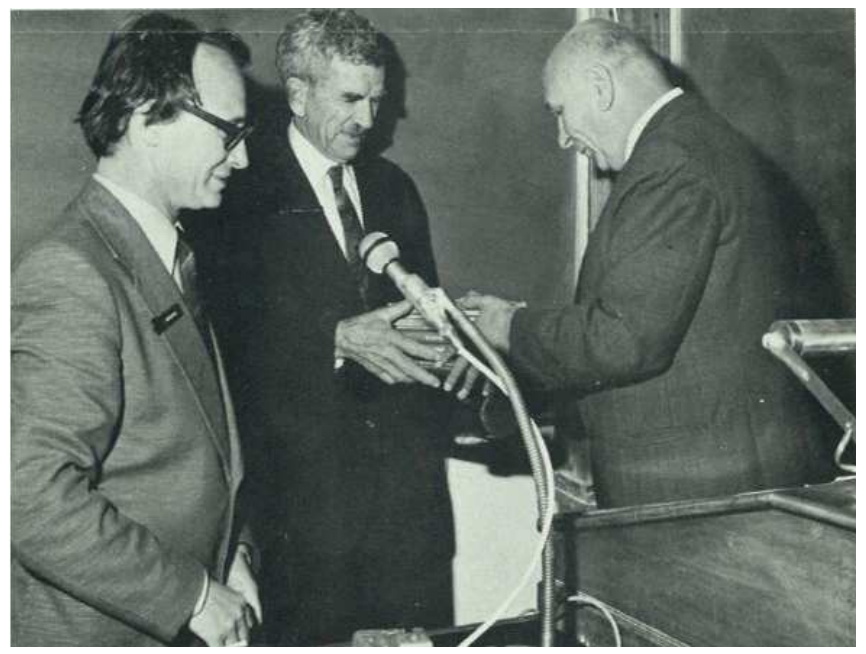

Figure 1. Academician A.V. Sidorenko presents Dr Norman Fisher, Chairman of the Organising Committee and President of the Congress $25^{\text {th }}$ IGC (centre), with the L.A. Spendiarov Prize.
The National Coordinator of the Excursion Committees was J.N. Casey (Australian Capital Territory). Regional coordinators were P.R. Evans (New South Wales), N. de B. Hornibrook (New Zealand), P.W. Crohn (Northern Territory), W. Manser (Papua New Guinea), V.G. Swindon (Queensland), R.K. Johns (South Australia), I.B. Jennings (Tasmania), M.A.H. Marsden (Victoria) and J.H. Lord (Western Australia).

In addition, a Sydney Committee chaired by G. (Toby) Rose handled all practical matters of Congress organisation in Sydney and vicinity. Six associated subcommittees, including a Ladies Subcommittee chaired by Mrs D.McGarry, provided support. Crucially, it appears that C.E. Marshall, Edgeworth David Professor of Geology until 1973, secured virtually free access to the University of Sydney for the numerous Congress meetings (Fig 2). Such generosity from an academic establishment would be unlikely today.

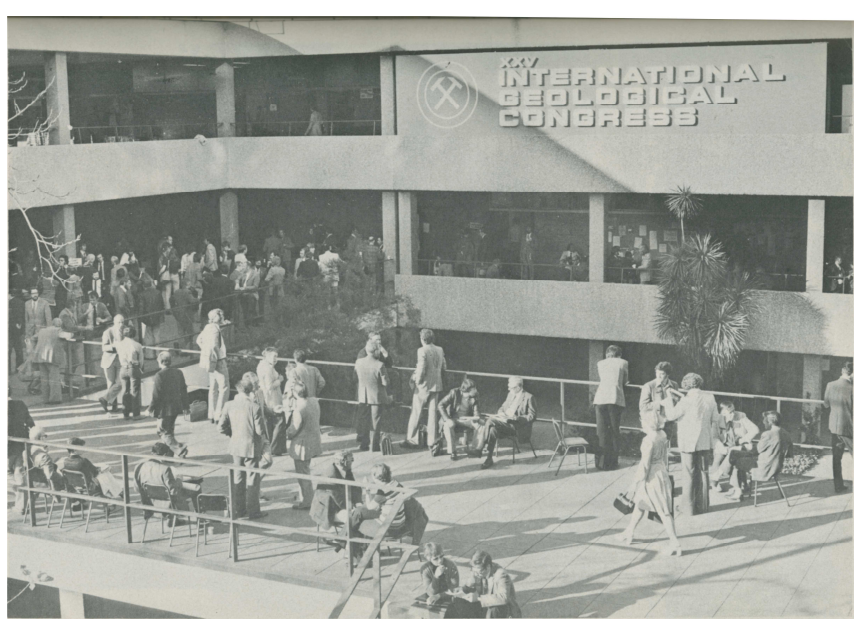

Figure 2. $25^{\text {th }}$ IGC Headquarters - The Carslaw Building, University of Sydney.

Constant worries about funding persisted until the final stages of Congress preparation. Even postage of notices to Australian geologists was subject to scrutiny. A two-person fund-raising committee set up in 1973 targeted the petroleum and mining industries for regular contributions over a three-year period!

\section{Attendance}

The First Congress Circular was sent to approximately 10,000 geologists worldwide. The total number of geologists who finally attended the $25^{\text {th }}$ IGC was 2953 , representing 83 countries. This compared with 3895 at the previous IGC in Montréal, Canada in 1972. Not surprisingly, the 1550 geologists from Australia also represented the largest gathering of Australian geologists up to that time. The next largest national delegations were from US (385), Canada (131), France (87), USSR (76), West Germany (64), UK (58), New Zealand (56) and Japan (53). Notably during that "Cold-War" era, there were separate delegations from the Federal Republic of Germany (West Germany) and the German Democratic Republic (East Germany).

A major issue at the Congress was the attendance of representatives of the People's Republic of China. Congress President N.H. Fisher and his BMR colleague and successor as BMR Director, L. Noakes, visited China in October 1974, and were impressed with their progress in geological research. Immediately before the Congress, China 
expressed interest in joining IUGS. However, Taiwan was then an IUGS member, officially named China. During the Congress, the IUGS Council voted on 19 August to admit China and cancel Taiwan's IUGS membership, only one representative being allowed per country. Even though it was too late to include papers from the Chinese delegation in the formal programme, publications on China's geology circulated soon after the vote. "The Development of Geological Work in China" by the delegation of the Geological Society of China (August 1976), a somewhat political 9-page document without illustrations or references, was widely distributed at the Congress. A special Chinese session covering the same topic was also added to the programme.

The former USSR also participated prominently in the Congress. Most of the large Soviet delegation travelled to Sydney by ship and was housed thereon in Sydney Harbour. The long transit time by sea had prevented many Russian geologists from registering for the conference or excursions. Language problems were prevalent, since English was the exclusive Congress language. Confusion arose about Soviet excursion registrations, apparently made by bureaucrats unfamiliar with Australian geology. For example, coal specialists were registered on a Carboniferous excursion to the volcanic rocks of the Hunter Valley. As a consequence, several Russian delegates made belated reassignments to different excursions.

A particularly notable Soviet delegate was V.V. Tikhomirov, founder of the International Commission of the History of Geological Sciences (INHIGEO) and of the history of geology discipline. Tikhomirov, a hero of the USSR (Malakhova, 2012) blinded through service in World War 2, had subsequently returned to active professional geological employment. At short notice, he was a late registrant for the Congress, replacing then INHIGEO Secretary, M. Guntau, from East Germany. The late change may have been the reason that no arrangements were made for a Soviet colleague to accompany him. That unfortunate circumstance meant that one author (DFB) became responsible for him at short notice. Fortunately, J. Ferguson of the technical staff at the Department of Geology, University of Sydney, was fluent in Russian and was quickly reassigned to assist Tikhomirov!

Some pre-congress excursions suffered from wet weather. As the Congress date approached fear grew that the Congress itself would be marred by Australian winter weather, much of the recreational area for the Congress being open air. Fortunately, the weather improved the day before the Congress opened, and a perfect week, weatherwise, ensued. Only a few participants from elsewhere in Australia (Jago, 2013) complained of the Sydney smog.

\section{Conference Publications}

The Sydney IGC was the first without publication of full papers. All accepted papers were published, but only as abstracts of 500 to 700 words (International Geological Congress, 1976) due to considerations during the 1972 Congress and the "rapidly increasing cost of printing". Contributors were encouraged to publish elsewhere, and many subsequently advised that their papers had been published in international journals, often in special volumes. However, one author (DFB) recollects that publication of education session papers suffered considerable delay.

All Congress delegates received the special issue of EarthSciences Review dedicated to the "The Geosciences in Australia" (Glaessner, 1976). Its ten general papers covered research into petrology, tectonics, geo-microbiology, geomorphology, palaeontology, environmental geology and the history of geology in Australia.

The most enduring Congress research publications were probably the Excursion Guides, 33 of which were issued for the extended preand post-Congress excursions and 20 for the short, weekend excursions. Their ongoing value results from their provision of information about important sites, some of which have since become difficult of access. Some Excursion Guides, prepared for field trips subsequently cancelled due to low registration, were published and sold with other guidebooks to supplement Congress income.

Many Australian geoscience organisations also offered special publications for the Congress. The BMR published three important geoscience maps for the event. One, a 1:2,500,000 geological map of the Australian continent, was the first national geological map since 1966, and it revealed much new information from recent geological mapping. Two new geophysical maps of the continent were also issued, one a 1:5,000,000 gravity map and the other a 1:2,500,000 magnetic map, the first such map of Australia (Wilkinson, 1996). In addition the University of Sydney issued a geological summary of the Sydney area for the use of delegates (Branagan et al., 1976).

A unique collaborative publication, History and Role of Government Geological Surveys in Australia, was offered by Geological Surveys around Australia through the initiative of R.K. Johns at the Geological Survey of South Australia (Johns, 1976, 2008).

Last but not least, the Congress inspired completion of a major monograph about the Geology of Victoria (Douglas \& Ferguson, 1976). Taking 15 years and coming to fruition after similar publications had appeared from all other Australian States, this successful effort by the Victorian Division of the Geological Society led to several revisions and updates (e.g. Birch, 2003).

\section{Opening ceremony, social functions and controversy}

As the Congress opening approached, worries that an "industrial strike" would affect the initial session at the recently opened Sydney Opera House thankfully receded. Preceding the official opening, music was supplied by organist Peter Kneeshaw on an electronic instrument (the large pipe organ not yet being completely installed) and a splendid, albeit brief, recital by the Australian Youth Orchestra conducted by Robert Pickler. A proposed musical composition for the occasion never eventuated.

The $25^{\text {th }}$ IGC was formally opened by the Australian GovernorGeneral, Sir John Kerr, on Monday afternoon 16 August 1976 in the Sydney Opera House (Fig 3). The Governor General occupies the office closest to that of national President or Head of State in Australia, whilst Queen Elizabeth II of England remains also "Queen of Australia" and formal Head of State. Despite his position, Sir John Kerr's opening of the $25^{\text {th }}$ IGC caused much controversy and discussion amongst Australian geologists.

In the year before the Congress, Australia experienced arguably its greatest constitutional crisis in government. The summary dismissal by Sir John Kerr, in his role of Governor General, in November 1975 of a national government led by Prime Minister Gough Whitlam under controversial circumstances had remained a highly polarising issue across Australia. Consequently, there was much discussion in the Advisory Council of the Congress about the prior invitation for Kerr 


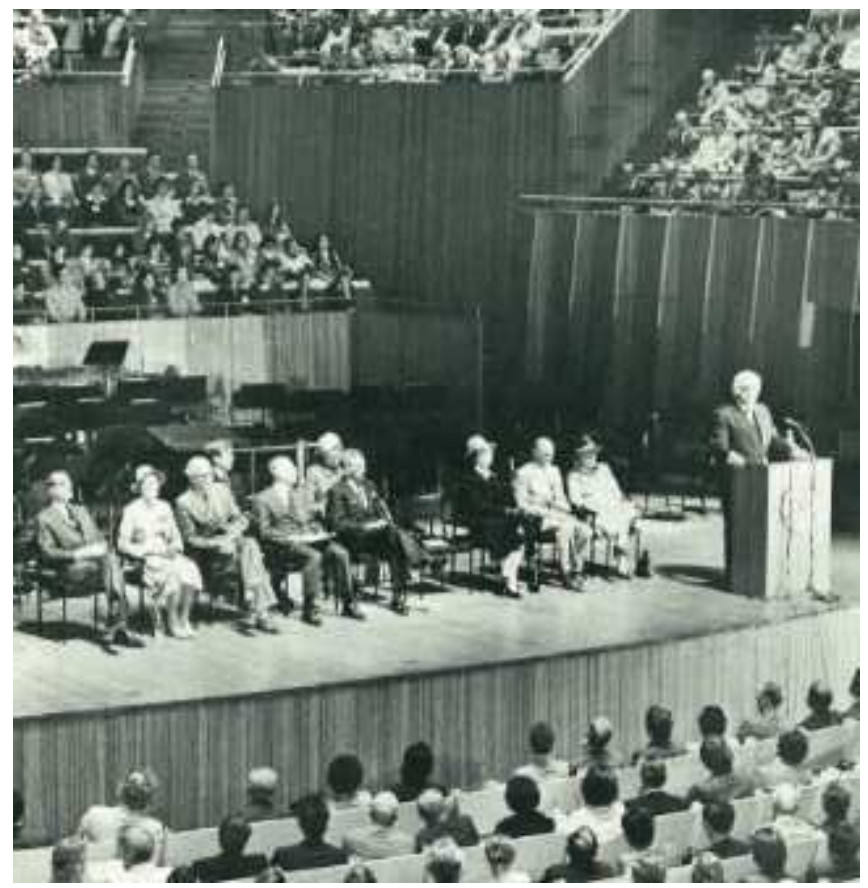

Figure 3. The Governor General of Australia, Sir John Kerr, addresses delegates at the Opening Ceremony of the $25^{\text {th }}$ IGC in the Sydney Opera House.

to open the Congress. Some members demanded withdrawal of the invitation, whilst others argued that the IGC had invited the 'office', not the man, and the offer should stand. The latter approach prevailed, but some Australian delegates refused to attend the opening ceremony, whilst there was also a significant on-site protest when a number of delegates (presumably Australian) rose from their seats and pointedly walked out of the ceremony as the Governor-General rose to speak. Many Australian delegates also recall that the Governor-General, having enjoyed a very good pre-opening lunch and accompanying libations, then proceeded to open the International "Geographical" Congress! That "gaffe" and his less than adequate speech were followed but not ameliorated, as one recorder notes, by a "second, much longer and very dull speech by a prominent geological writer"!

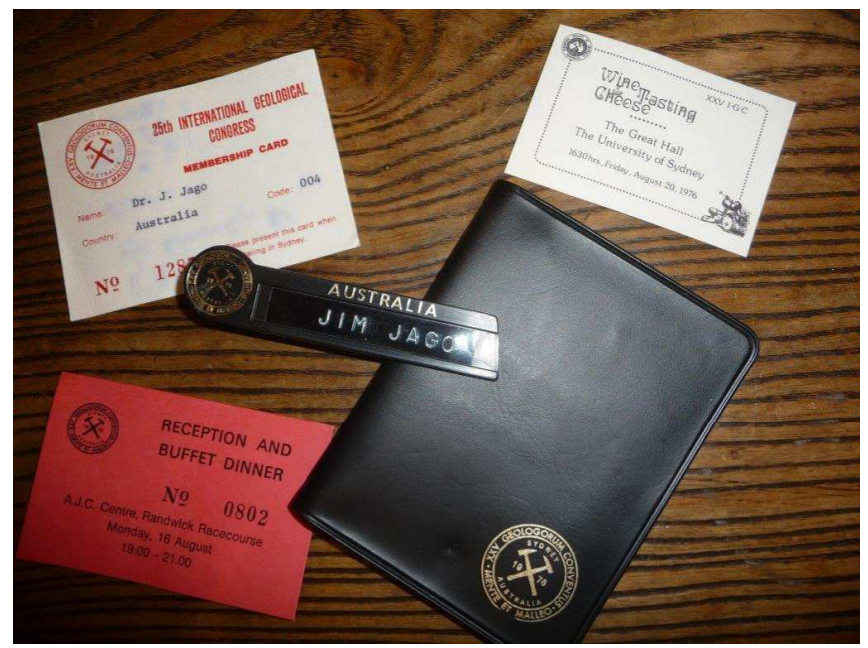

Figure 4. J.B. Jago's personal mementos of the $25^{\text {th }}$ IGC include tickets to the wine and cheese tasting in the Great Hall and to the reception and buffet dinner at Randwick Racecourse.
Another memorable event in the Congress social programme was the Friday evening wine and cheese soirée in the prestigious Great Hall of the University of Sydney, hosted by the Department of Geology at the University and the Geological Society of Australia (Fig. 4). It was scheduled to commence at $5 \mathrm{pm}$ with short introductory musical entertainment. One author (DFB) was conductor of the "The Sans Tones" choir, scheduled to give a recital of specially selected madrigals and mining melodies with organ accompaniment. Unfortunately, some technical sessions finished early, and the large crowd gathering before $4 \mathrm{pm}$ caused refreshments to be supplied early. By the time of the official beginning there was considerable merriment and little interest in listening to music. The choir did try, but not even the utmost power of the organ could compete with the noise of conversation. Wisdom prevailed, and the choir adjourned to a nearby room, where a few faithful followers indicated some appreciation for its efforts! Many delegates still remember the innumerable broken wine glasses on the historic marble floor of the main hall. Depending on one's point of view, the soirée could be regarded as either a triumph or a disaster. As one participant in a subsequent weekend field trip recalled, "That was quite a party".

Several other functions enhanced the social programme. The principal dinner was held at Randwick Race Course, the only venue in Sydney capable of seating 3,000 people. Attendees were welcomed outside by a military band and entertained inside by a small orchestra. An "Auld Lang Syne Party" at the same location concluded the Congress, again with entertainment by a small orchestra (Fig 5).

A special Congress performance by the Australian Chamber Orchestra was arranged in the Music Room of the Sydney Opera House, and all 400 tickets were taken. Music by Mozart, Haydn and Australian composer, Peter Sculthorpe, filled the programme. In addition, a block of 500 tickets reserved for Congress delegates for a performance of Mozart's Opera "Il Seraglio" at the Sydney Opera House nearly sold out.

\section{Scientific and Technical Programme}

Of the 1148 technical papers programmed, 964 technical papers were presented at the Congress. During each morning of the Congress, 17 disciplinary Sections were organised on subjects ranging from traditional topics, such as mineralogy, petrology, palaeontology and stratigraphy, to more modern research areas, such as marine geology, planetology and database development/mathematical

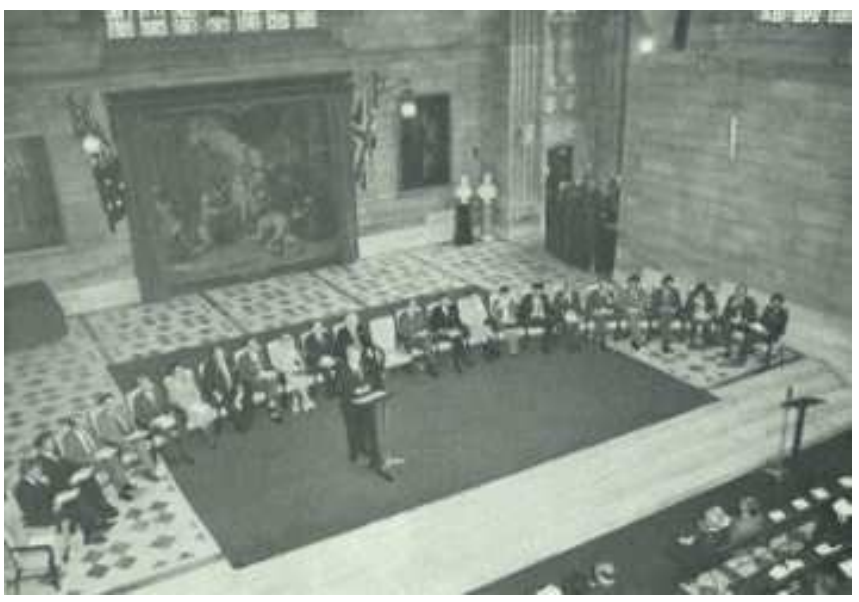

Figure 5. The Closing Ceremony at the University of Sydney. 
geology. Mineralogy figured largest, with a suite of 12 sessions including 82 listed presentations, also constituting the $10^{\text {th }}$ meeting of the International Mineralogical Association.

During afternoons, specialist symposia were organised mostly by invitation on subjects of current importance. The following list provides an excellent perspective on the diverse and distinctly modern subjects then commanding the interest and attention of geologists around the world and of Australian geologists in particular:

- Earliest Archaean tectonics and magmatism

- Geology and petrology of the crystalline domains of the earth's crust

- Experimental petrology related to extreme metamorphism

- Structural characteristics of tectonic zones

- The structure of Australia and variations in tectonic style

- Stress environment and displacement at continental margins

- Past distribution of continents

- Correlation of geological events in some orogenic belts and their forelands

- Metallogenesis and the new global tectonics

- Uranium geology

- Fluid inclusions

- Experimental geology of the genesis of ore deposits

- Continental arid climate lithogenesis

- Shallow marine and non-marine carbonate sedimentation

- Aspects of the formation of mobile belt sediments

- The international geochronological scale

- Trace fossils

- Economic geology of the sea floor (excluding fuels)

- Active plate boundaries of the western Pacific

- Circum-Antarctic marine geology

- Deep Sea drilling results in the Indian Ocean

- Geological hazards and the environment

- Data storage and retrieval for developing countries

- Random events in geology

- Quantitative strategy for resource exploration

- The growth of geological knowledge in the age of geographical exploration

Not surprisingly, given the numerous Australian geologists then employed in mineral exploration, more papers were offered in sessions dedicated to mineral deposits than in any others. The principal interest of most delegates was also mineral deposits. A specialist symposium on the Geology and Geochemistry of Manganese alone attracted 58 abstracts.

For similar reasons the sessions dealing with Recent Advances in Exploration Geophysics attracted more than 70 papers. The rare interaction of Soviet and Australian geologists in these economic geology sessions would have been most interesting.

Significant numbers of presentations concerned plate tectonics, which had gained acceptance over the previous decade. Precambrian geology and deep sea drilling also generated much interest and attracted numerous contributions.

The largest audiences, approaching 300, were observed in sessions dealing with Circum-Pacific plutonism, exploration geophysics, uranium geology, mineral deposits, tectonics and Precambrian geology.

Notably the Sydney IGC was the first following the formal establishment of the International Geological Correlation Programme (IGCP) in early 1973. Over the previous decade Australia had contributed significantly to this development (Harrington, 1994). Specialist Congress symposia sponsored by IGCP projects concerned:

- Earliest Archaean tectonics and magmatism

- Circum-Pacific plutonism

- Tectonic aspects of ophiolites

- Global correlation of epochs of folding

- Correlation of kaolin genesis and age

- Precambrian / Cambrian boundary problem

\section{Promotion}

Public lectures were also a Congress feature, with notable lunchtime presentations including:

- Viking observations of Mars (given on two occasions by L.T. Silver)

- New light on the Moon (by U. Marvin)

- Environmental management and the geologist (by P. Ellis)

Despite advance notices in Sydney newspapers, wider community attendance at these public lectures was poor. Disappointingly, reporting of the Congress generally was neglected by the local media (Branagan 1976a). The only Sydney newspaper with any coverage was the Italian language newspaper!

With organisers focussing on encouraging the involvement of Australian geologists and making the event a success for visiting geologists, local media contact may have been overlooked. After the event, the Congress was highlighted in the University of Sydney Union Recorder (Branagan, 1976b). The Congress had also received advance promotion in the international geological news journal, Geotimes (Branagan 1976c), which also published a post-Congress review in November 1976.

Another promotional disappointment was failure to achieve issue of an Australian postage stamp celebrating the Congress. Such postage stamps had been a feature of earlier Congresses. The initiative of Congress President N.H. Fisher apparently failed due to a dispute between high level public servants!

\section{Exhibitions and Films}

By the mid-1970s, organisational stands, displays and film showings were common in conferences, not least the IGC (Fig 6). Separate pamphlets listed those events.

Some of the representative organisations with promotional booths at the $25^{\text {th }}$ IGC were:

- Geological Surveys of New South Wales, South Australia and Victoria as well as the BMR

- Geological Surveys of Canada, India, Japan, Netherlands, New Guinea, New Zealand, United States and Federal Republic of Germany

- Academy of Geological Science, People's Republic of China

- Bureau de Researches, Geologique et Minieres, France

- Consiglio Nazionale delle Ricerche, Italy

- UK Institute of Geological Sciences

- USSR Ministry of Geology

- National Oceanic and Atmospheric Administration, USA

- CSIRO Mineral Research Laboratories, Australia

- Australian Mineral Development Laboratories (AMDEL) 


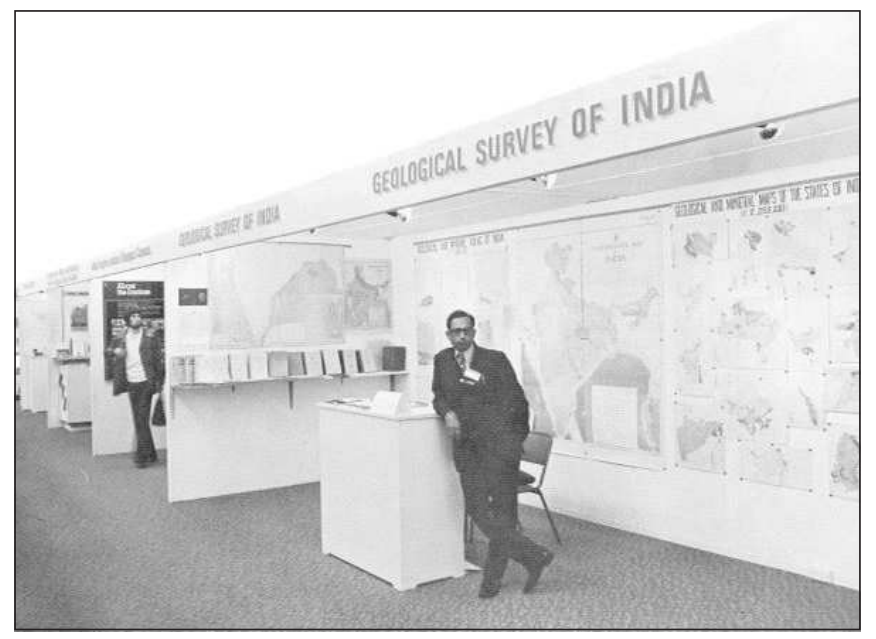

Figure 6. The scientific exhibition at the $25^{\text {th }} I G C$.

- CRA Exploration Pty Ltd

- Geopeko Limited

- DA Book depot

- UNESCO Press

The Macleay Museum at the University of Sydney had special displays contributed mainly by Museums and Geological Surveys from around Australia. Assistance from T.A. Darragh, National Museum of Victoria, was especially notable in this success. Displays included:

- Seismic geology of the Sydney district

- A thin section across the lithosphere

- Early Geological Maps (including a copy of P.E. Strzelecki's giant 1845 map and geological sections of Eastern Australia)

- Broken Hill minerals

- Arkaroola, South Australia

- Upper Devonian fossils of New South Wales

- Nickel Ores and Minerals of Western Australia

- Iron Ore, Western Australia

- Agate Creek, Queensland

- Mineralisation of Wolfram Camp, Queensland

- Zeolites of Victorian Tertiary basalts

- Birds of Victoria's past

- Victorian Ordovician graptolite zones

- Oil Shale, Glen Davis, New South Wales

- Metalliferous mining, New England, New South Wales

- Gold, New South Wales

The Fisher Library, University of Sydney also displayed a wide range of classic geological books ranging from the $16^{\text {th }}$ century onwards (Branagan, 1976d).

A large selection of films was also shown in the Stephen Roberts and Edgeworth David Theatres, University of Sydney (Fig 7). These screenings were well attended, as the quantity of geological films appearing by the 1970 s were appreciated for their educational value at both secondary and tertiary levels. Titles included:

- Broken Hill mining

- Sand harvesters (mineral sand mining, Australia)

- Stromatolites (Western Australia)

- Desert landforms

- Lyell on Etna (an historical perspective)

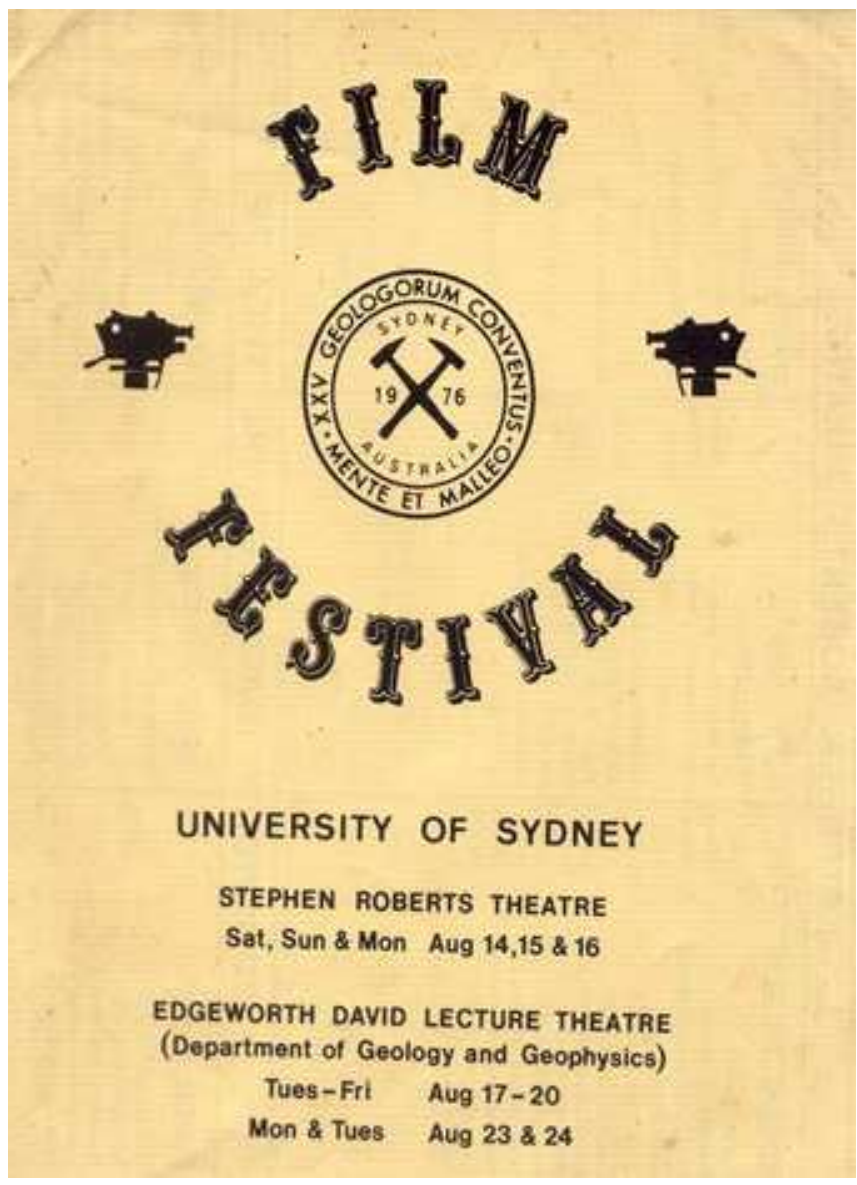

Figure 7. Cover of the $25^{\text {th }}$ IGC film programme.

- Search for coal (Queensland)

- All you have to do is dig (Australian Opal)

- ERST (NASA satellite)

- Paricutin (volcano in Mexico))

- Ngauruhoe erupts (New Zealand volcano)

- Fire under the sea (pillow lavas)

- Guatemala 1976 earthquake

- Plate tectonics and the Kilauea volcano

- Carbonate and supratidal sedimentation, Bahamas

One film anticipated to be a highlight of the Congress, was "The Talgai Skull”, prepared by N.W.G. MacIntosh, Emeritus Professor of Anatomy, University of Sydney. It told the history of a human skull discovered in southern Queensland in the late nineteenth century, which came into prominence in 1914 when T.W. Edgeworth David presented new research and estimated the age of the skull as perhaps 40,000 years old. MacIntosh had carried out further research at Talgai in the 1960s. After agreeing to show the film, he became involved in a controversy with indigenous Aboriginal activists, and it was withdrawn from the Congress.

\section{Excursions}

The comprehensive field trip programme was a vital aspect of the $25^{\text {th }}$ IGC, despite the often remote and inaccessible nature of many valuable geological sites (Fig 8). The ready availability of air transport (often with special charters) enabled access to a huge area, extending from Western Australia to New Zealand and from Papua New Guinea 


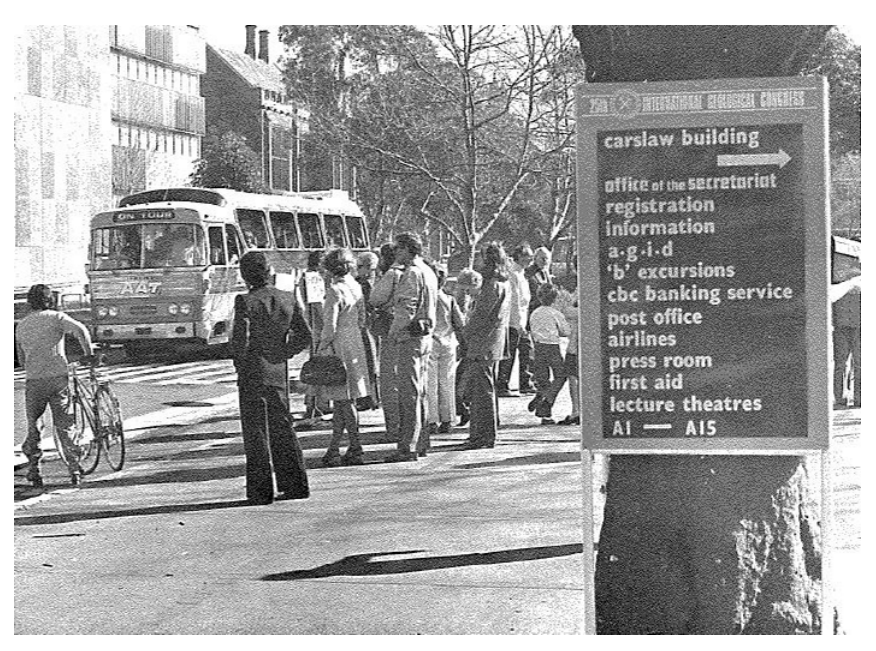

Figure 8. Excursion Departure Point, $25^{\text {th }}$ IGC.

to Tasmania, within a few hours. Four-wheel drive vehicles, helicopters and boats facilitated surface travel and suitable logistics support. In all, 1095 Congress delegates took part in the formal excursions. The International Mineralogical Association, whilst contributing greatly to the Congress sessions and exhibitions, organised its field trip to the Flinders Ranges, Olary and Broken Hill apart from the Congress organisation (Birch, 1976; Depledge, 1976). Other informal field trips also occurred. For example, Harrington (2007) reports being surrounded at the Congress Opening by 9 or 10 Indian geologists requesting a field trip to the distant Bowen Basin in Queensland. The problem was solved by J.N. Casey, from BMR, who quickly arranged a 3-day, fly-in fly-out trip fully sponsored by the mining company. From a modern perspective, it is difficult to appreciate the potential accommodation problems in regional areas in1976, when a proposed Melbourne-Sydney Excursion for 600 participants never eventuated. Reduced government funding support following a change in the Federal Government in November 1975 caused cancellation of other trips.

In the final result, the short or weekend field trips numbered 21 and were mostly based around Sydney, Newcastle and Canberra. However, even the weekend field trips included more distant locations, such as the Broken Hill lead-zinc-silver mine and the Lightning Ridge opal field, both fully booked before the Congress. The trip examining Sydney's historic sandstone buildings was free-of-charge.

One short/weekend excursion, the first southern hemisphere field trip offered by the International Commission on the History of Geological Sciences (INHIGEO), was "Aspects of the History of Geology in Eastern Australia". Led by T.G. Vallance and D.F. Branagan, "it traced the routes of Australia's early explorers and pioneer geologists, westwards from Sydney to Orange and visited the site of Australia's first goldfield (Ophir 1851). Particular attention was given to interpretations by early geologists of problematic Palaeozoic and Mesozoic stratigraphy and the origins of the spectacular valleys carved in the Triassic rocks of the mountains" (Vallance, 1977).

Arguably the extended pre- and post-Congress field trips were the highlight of the IGC. Nine popular excursions were offered twice, before and after the Congress:

- "Precambrian geology of the Mount Isa region", led by G.M. Derrick and I.H. Wilson (total attendance 81)
- “Mining centres of northern Australia", led by G.R. Ryan (total attendance 63)

- "Mining centres of southern and western Australia" led by L.C. Ranford and J.H. Lord (total attendance 60)

- "Ore deposits of western Tasmania", led by M. Solomon and G. Green (total attendance 57)

- "Great Barrier Reef, Queensland", led by W.G. Maxwell, J.S. Jell and G.R. Orme (total attendance 55)

- "Neotectonics, earth deformation, structural geology, metamorphics of Wellington and the South Island (northern part), New Zealand" led by G.W. Grindley, C.J. Lensen (total attendance 49)

- "Recent volcanoes and mineralization in Papua New Guinea" led by R.J. Cooke and J. Baldwin (total attendance 43)

- "Devonian reef complexes of the Canning Basin" led by P.E. Playford, A.E. Cockbain and M. Johnstone (total attendance 30) (Fig 9)

- Carbonate sediments of the west coast of Western Australia led by B. Logan (total attendance 16)

Excursions to Australia's thriving mining operations were most popular, notably Mount Isa (which was promoted as the world's biggest lead producer), Mary Kathleen (an open-cut uranium mine) and the classic Broken Hill mines, as well as the Bougainville copper operation in Papua New Guinea (which no longer operates). These trips of up to 11 days with motel/hotel accommodation in mining centres attracted mainly non-Australian participants. An unfortunate incident was the refusal by the conservative mine operators at Mount Isa to allow a female Congress delegate from the US to enter the underground mine. Another mining excursion, led by A.F. Trendall and J.G. Blockley, involved a visit to the iron ore and asbestos mines of Western Australia's Pilbara region (Fig 10). Blockley (2012) recalls the total lack of concern about the health hazards of fibrous asbestos and the dangers of climbing without ropes at Joffre Falls and accessing precipitously deep Red Gorge. In today's safety conscious times access would not be allowed!

Other extended excursions included visits to regions rarely seen by geologists and only recently investigated in detail. Such excursions were "safari-type" with travel in four-wheel drive vehicles and well-

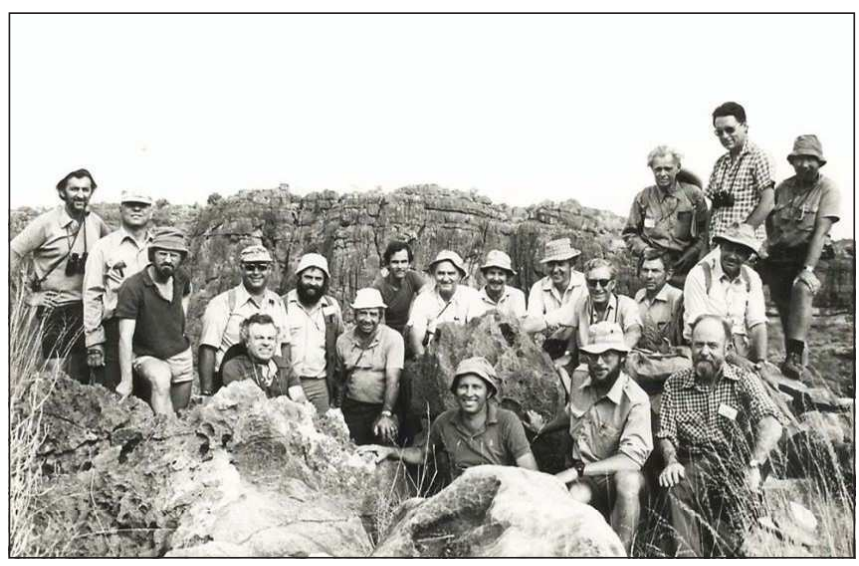

Figure 9. Participants on 25th IGC Excursion 38A - Devonian Complexes of the Canning Basin - Safari Type Excursion. Excursion Leader, Phil Playford, is in the middle, with colleague Murray Johnstone, on his left, behind a rock. A third leader, Tony Cockbain, is on the extreme right. 


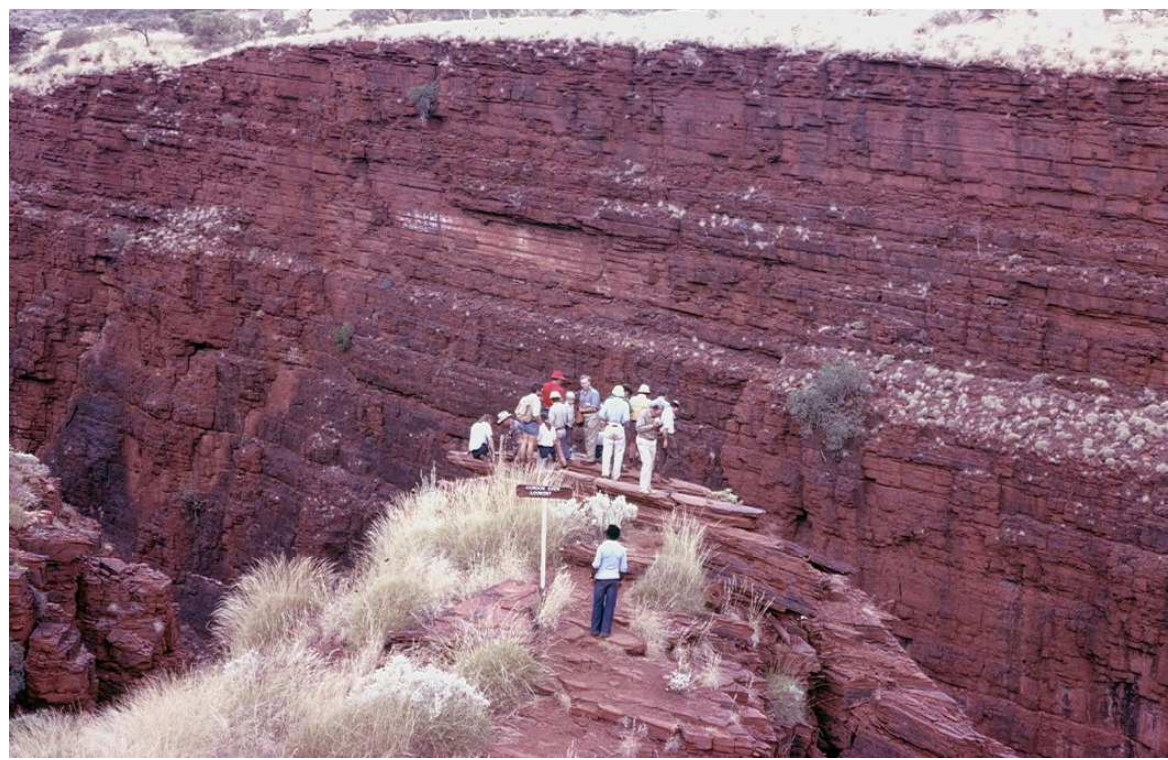

Figure 10. 25 ${ }^{\text {th }}$ IGC Excursion 43A to Hamersley Basin, Western Australia, at Oxers Lookout where the lower part of the 370m-thick Paleoproterozoic Joffre Member of the Brockman Iron Formation is exposed in Red Gorge. Excursion leader, Alec Trendall, is dressed in red shirt and hat.

planned camp sites in the Australian outback. Charter flights, helicopters and motor launches also provided access. These excursions were as follows:

- "Cambrian and Ordovician biostratigraphy of the east Georgina Basin, Queensland" led by E.C. Druce and J.H. Shergold

- "Cainozoic volcanicity, North Queensland", led by P.J. Stephenson

- "Palaeozoic accretion of eastern Australia (across New South Wales)" led by E. Scheibner and D.J. Pogson

- "Devonian reef complexes of the Canning Basin, Western Australia" led by P.E. Playford, A.E. Cockbain and M. Johnstone

- "Precambrian geology of the Kimberley region, Western Australia-Northern Territory" led by K.A. Plumb and R. Halligan

J.B. Jago (2013), who attended the Georgina Basin excursion, recalls that the number of participating Cambrian and trilobite specialists was so large that an Australian outback plane crash could have decimated world Cambrian expertise!

Excursion leader P.E. Playford (2008) confirmed that the two Canning Basin excursions (with the maximum allowed 30 participants) were the first ever international visits to the famous Devonian reefs. He recalls the following:

"The excursions began with a flight from Derby to Christmas Creek in a Twin Otter (high-wing) turboprop aircraft, to gain an overview and take photos of the reef complexes. Participants were then met at Christmas Creek by the tour contractor who drove them to Cave Spring (Mimbi) where they camped for three nights. Over the seven-day excursion they examined the reef complexes in the Bugle Gap area, Geikie Gorge (by boat), Dingo Gap, the Elimberrie Bioherms, the Oscar Range, and Windjana Gorge".

"The excursions were judged to have been very successful and participants gained an excellent overview of these remarkable exposures. For most it was the first time that they had camped in the
Australian bush. They also enjoyed seeing many examples of Aboriginal rock art in caves in the limestone. It was through the excursions that the Devonian Great Barrier Reef first gained wide recognition as one of the iconic features of world geology. It led to an invitation for Playford to become a Distinguished Lecturer of the American Association of Petroleum Geologists, speaking on the reefs throughout the US and Canada. This was followed by lecture tours in Australia as a Distinguished Lecturer of the Petroleum Exploration Society of Australia, in England and Europe as a Guest Fellow of the Royal Society of London, and in China as an exchange scholar of the Australian Academy of Science and Academia Sinica".

The $25^{\text {th }}$ IGC excursions to New Zealand and Papua New Guinea deserve special mention. Six separate New Zealand excursions, organised therewith the outstanding involvement and support of the New Zealand Geological Survey, covered all aspects of the geology. The organisation of two field trips to newly independent Papua New Guinea was similarly supported and successful.

\section{Finance}

Given the expanding nature of past Congresses, there was significant and ongoing concern about finances. A provisional budget prepared as early as March 1972 was revised following receipt of Government and company sponsorship in July 1973 and March 1976 respectively. The Congress agreement between the Australian Academy of Sciences and the Geological Society of Australia was for the Academy to have responsibility for finance, and shared responsibility with GSA for the overall Congress organisation. There was some antagonism concerning this arrangement, notably between M.F. Glaessner representing the Academy and N. H. Fisher representing the Geological Society.

With the Montréal Congress organisers suggesting that a $\$$ US100 Congress member fee should be charged, the Organising Committee opted for a $\$ A 60$ fee rising to \$A75 after February 1976. This reflected an anticipated reduction in printing expenses.

As the time of the Congress approached, listed excursions with little response were cancelled and committee members were advised to curb expenses. On the other hand, direct grants were obtained from the New South Wales and Australian Governments totalling \$A10,000 and $\$ A 7,000$ respectively. In addition, significant sponsorship totalling almost \$A20,000 was obtained from the mining industry (40 companies) and the petroleum industry (20 companies). After the Congress the cost of government and other institutions providing voluntary service to the Congress was valued somewhere between \$A350,000 and \$A400,000.

At the opening it was quickly realised that the Congress would be profitable due to unexpectedly high excursion attendance and about 300 late Congress enrolments. By 1977, the estimated Congress profit exceeded \$A40,000. Soon after the Australian Academy of Science developed plans to incorporate the profit into its general revenue. 
Members of Geological Society, who had contributed greatly to the Congress, were offended and its then President, S.W. Carey, challenged this plan.

An academician from Tasmania, who had been intimately involved in the organisation of the Congress, Carey telephoned Canberra to have the Academy vote deferred, travelled there and mounted a very determined effort against the proposal. Heeven threatened to blacken the international reputation of the Academy, if the funds were not put into an account to send young geologists to future international meetings (sponsorship not available for the Sydney Congress). Ultimately the Academy was forced to concede (Harrington, 2007). Since 1981, the $25^{\text {th }}$ IGC profit has also been used to fund both the Mawson Medal and the Lecture that is presented by an outstanding contributor to earth sciences in Australia at the biannual "Australian Earth Sciences Convention".

The final "wrap-up" of the organising Committee (Branagan, 1977) reported the uses of the profits and noted that the venue had been excellent.It also recorded that presentations, although variable, averaged a little better than at earlier Australian conferences. A Public Relations Committee should have been established, whilst the final Auld Lang Syne party should have been free and at a different venue. The greatest saving resulted from not publishing the full text of papers. The hospitality room had been an outstanding success, contributing to the "atmosphere of friendly informality", and reportedly serving approximately 40,000 cups of coffee!

Organising the Congress would have been impossible without the cheerful assistance of numerous un-named typists and draughtsmen and -women, who prepared the vast amount of typed and pictorial material.

With regard to the international geological scene, the authors agree with G.B. Vai's conclusions concerning the second International Geological Congress, held at Bologna, Italy in 1881. Vai comments that the IGC enabled "geology to obtain its autonomy and identity as a science through a common language", and "the IGC developed a special structure in view of its unique function of maintaining and improving the cultural identity of the geological sciences and their advancement"(Vai 2004).

\section{Some lighter moments}

Once it was realised that the Congress would not bankrupt the various bodies involved, a few light-hearted initiatives were supported. A reverse logo commemorating the Congress became available which could be ironed on to a fresh white T-shirt. The small " cookbook" brochure on preparing Australian animals for the table remains today an item of publication curiosity. After preparing numerous official brochures, one draughtsman was inspired to create a notice (not altogether inappropriate) announcing the award of a prize for the "worst slide" projected at the Congress!

\section{Epilogue}

Both authors of this article had the privilege of attending the $25^{\text {th }}$ IGC and feeling its excitement. They also appreciate the $25^{\text {th }}$ IGC's major importance for Australian and international geology.

As Senior Lecturer in Geology at the University of Sydney, DFB was significantly involved as Convenor and Presenter in the Symposium on Geological Education, Member of the Local Excursions Subcommittee, Conductor of the The Sans Tones, joint
Excursion Leader of the Aspects of the History of Geology in Eastern Australia field trip, as well as being a co-author of a supporting geology book on the Sydney Basin. Life seemed dull and unexciting after the event.

BJC was then a youthful, recent addition to the geological profession with the Geological Survey of South Australia, with the 1976 Sydney Congress providing for him a 2-day overland drive from Adelaide to Sydney in convoy with several colleagues, and a gathering of geologists like none before. Although not a formal Congress presenter, he did give a technical presentation to an informal meeting of international fossil conodont workers, likely the first "Pander Society" meeting in Australia. That opened the personal opportunity for a visiting professorial appointment at the University of Waterloo, Ontario, Canada, 2 years later. A small white marble paper weight with $25^{\text {th }}$ IGC insignia attached, which accompanied the conference registration folder, is retained as an enduring Congress memento.

\section{Acknowledgements}

This paper has been facilitated by the personal memories of many Australian geologists over many years. P.E. Playford and J. Blockley provided two specific excursion images for this paper. J.B. Jago and P.E. Playford also provided an early review of the manuscript, which added a new perspective. The late H.J. Harrington sent an extensive handwritten letter that also added much to the content. The University of South Australia provided an excellent working environment for BJC to undertake historical research.

\section{References}

Birch, W.D., 1976,The I.M.A. excursion to the Flinders Ranges, Olary and Broken Hill areas: Australian Mineralogist v. 1, pp. 29-31.

Birch, W.D., ed, 2003,Geology of Victoria: Geological Society of Australia, Special Publication, no. 23, 842pp.

Blockley, J., 2012, $25^{\text {th }}$ IGC Excursion 43a - A pictorial memoir: Newsletter, Earth Sciences History Group, Geological Society of Australia, no. 43, pp. 24-31.

Branagan, D.F., 1976a, Editorial: The Australian Geologist, Newsletter of the Geological Society of Australia, no. 11, pp. 1,3,15-16.

Branagan, D.F., 1976b,Geology Congress: Union Recorder, University of Sydney, v. 56, pp. 4-5.

Branagan, D.F., 1976c,International Geological Congress: Geotimes, v. 21, pp. $12-14$

Branagan, D.F., 1976d, Backward glances - A book review: The Australian Geologist, Newsletter of the Geological Society of Australia, no. 12, pp.5-6, 14-15.

Branagan, D.F., 1977, The last lays of the $25^{\text {th }}$ IGC: The Australian Geologist, Newsletter of the Geological Society of Australia, no. 14, pp.5, 14.

Branagan, D.F., 1994, The International Geological Congress, in More Rocks, Fossils, Profs, The Department of Geology \& Geophysics, University of Sydney, 1972-1992, pp. 27-28.

Branagan, D.F., 2012, Fleshing out the landscape: Two centuries of Australia's geological heroes: Episodes, v.35, pp. 44-56.

Branagan, D.F and Darragh, T.A., 1976, $25^{\text {th }}$ International Geological Congress: A Special Exhibition by the Macleay Museum, 11 pp.

Branagan, D. F., Herbert, C. and Langford-Smith, T., 1976,An outline of the geology and geomorphology of the Sydney Basin: Science Press, 60 pp.

Cooper, B.J., 1994,Chapter One: The development of a national geological society, in Cooper, B.J. and Branagan, D.F., Rock Me Hard,Rock Me Soft: A history of the Geological Society of Australia: Sydney, Geological Society of Australia, 194pp.

Depledge, R., 1976, The $25^{\text {th }}$ International Geological Congress and mineralogical museums: The Australian Mineralogist, v. 1, pp. 27-28. 
Douglas, J.G. and Ferguson, J.A., eds, 1976,Geology of Victoria: Melbourne, Geological Society of Australia, Special Publication no. 5, 528pp.

Edwards, A.B., ed, 1953. Geology of Australian ore deposits: Publications, $5^{\text {th }}$ Empire Mining and Metallurgical Congress, Australia and New Zealand, 1953, v. 1, 1290pp.

Glaessner, M.F., ed, 1976, The geosciences in Australia: Earth Sciences Review, v. 12, pp. 99-346.

Harrington, H.J.,1994, The Australian origins of the IGCP (International Geological Correlation Programme): 12th Australian Geological Convention, Perth WA, September 26-30, Geological Society of Australia, Abstracts, no. 37, p. 166.

Harrington, H.J., 2007, Personal communication, " $25^{\text {th }}$ International Geological Congress, Sydney 1976”, letter to B.J. Cooper, 12 April, 5 pp.

International Geological Congress, 25 $5^{\text {th }}$ 1976, Abstracts. Canberra; Union Offset Company Pty Ltd, v. 1 (Sections 1-7), pp.1-334; v 2 (Sections 817) pp. 335-662); v 3 (Sections 102.1-117.2) pp. 663-936.

Jago, J.B., 2013, Personal communication, November.

Johns, R.K., ed, 1976, History and Role of Government Geological Surveys in Australia: South Australia, Government Printer, 111pp.

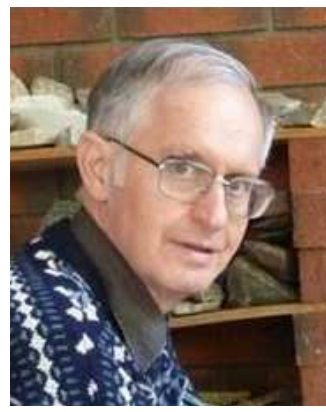

Barry Cooper holds an MSc from the University of Melbourne and a $\mathrm{PhD}$ from Ohio State University. During the 1980s and 1990s Barry commenced investigations first into the history of geology and later in dimension stone geology. In 'retirement' as Associate Professor at the University of South Australia, he has been one of the leaders in advocating formal designation of those natural stones that have achieved widespread recognition in human culture. Barry is currently Secretary General of both the Heritage Stone Task Group (HSTG) and the International Commission on the History of Geological Sciences (INHIGEO).
Johns, R.K., 2008, Background story to the publication of the book 'History and Role of Government Surveys in Australia': Newsletter, Earth Sciences History Group, Geological Society of Australia, no.39, pp. 6-8.

Malakhova, I., 2012, The phenomenon of Vladimir Tikhomirov: International Commission on the History of Geological Sciences (INHIGEO) Newsletter, no. 44, pp. 55-61 (also available at www.inhigeo.org)

Playford, P.E., 2008, Personal communication, October.

Renwick, A.R., compiler, 1977, 25th International Geological Congress, General Proceedings: Canberra, Australian Academy of Sciences, Geological Society of Australia, International Union of Geological Sciences, 244pp.

Schneer, C., 1995, The geologists at Prague: August 1968. History of the International Union of Geological Sciences: Earth Sciences History, v. 14, pp. 172-201.

Vai, G., 2004, The Second IGC, Bologna, 1881: Episodes, v.27(1), pp. 13-20. Vallance, T.G. 1977. History of Geology at the $25^{\text {th }}$ International Geological Congress, Sydney, Australia: INHIGEO Newsletter, no. 11, pp. 4-6 (also accessible at www.inhigeo.org)

Wilkinson, R., 1996, Rocks to Riches: The story of Australia's national geological survey: St. Leonards (NSW), Allen \& Unwin, 446pp.

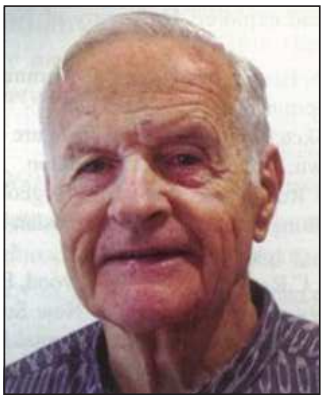

David Branagan is an Honorary Research Associate in the School of Geosciences, University of Sydney, where he was a teacher and researcher between 1959 and 1989, mainly in engineering geology and photo-interpretation. He has published a number of books and papers on aspects of Australian geology and its history. David was foundation editor of "The Australian Geologist" (1974-1984) and is an Honorary Life Member of the Geological Society of Australia. He was President of the "International Commission on the History of Geological Sciences" (1992-1996) and was awarded the Tom Vallance Medal by Geological Society of Australia in 2012 for his contribution to the history of geology. David was also awarded an Honorary DSc by the University of Sydney in 2007. 